\title{
Expansion behavior, growth and survival of the sea anemone Stichodactyla haddoni (Saville-Kent, 1893) with anemonefishes in captivity
}

\author{
J. Balamurugan ${ }^{1 *}$, T.T. Ajith Kumar ${ }^{1}$, Swagat Ghosh² \\ ${ }^{I}$ Centre of Advanced Study in Marine Biology, Faculty of Marine Sciences, Annamalai University, \\ Parangipettai-608502, Tamil Nadu, India. \\ ${ }^{2}$ Centre for Marine Living Resources and Ecology, Kochi, Kerala, India. \\ E-mail:rjbala.mbt@gmail.com
}

ABSTRACT: The sea anemone Stichodactyla haddoni's growth, expansion and survival under captivity at different conditions were studied for a period of 168 days. Each experiment with the same animals was continued after a resting period of 8 weeks in between. The trials were conducted under standardized conditions of water quality and photoperiods. The anemones were kept in two different groups, one with anemonefishes and the other without fishes. The expansion and growth rate in these two groups were assessed at weekly intervals. It was seen that in comparison with anemones made to live in solitude, those allowed to cohabitate with anemonefishes showed higher rate of oral disc expansion $(p<0.01)$ and a significant variance in the growth rates and it depends on the species of fish cohabitating with the anemone $(\mathrm{p}<0.05)$. Exponential growth rates was shown by anemones cohabitating with native species (fish live with a specific anemone in nature) and this was reversed in anemones lives with non-native species. The growth rates of anemones lives with the presence of anemonefish were 10-15\% higher than the anemones lives in solitude. During forced starvation, the survival rate of the anemones living with fish was $80 \%$ and the same was $60 \%$ in the anemones survived without fish. Chi-Square test confirms the presence of significant association linking the behavior of anemones and anemonefishes in their natural habitats $\left(\chi^{2}=25.019\right.$, df $\left.(7), \mathrm{p}<0.01\right)$. Results of this experiment reveal that $S$. haddoni shows enhanced expansion, growth and survival in the presence of anemonefishes. How to cite this article: Balamurugan J., Ajith Kumar T.T., Ghosh S., 2014. Expansion behavior, growth, and survival of the sea anemone Stichodactyla haddoni (Saville-Kent, 1893) with anemonefishes captivity // Invert. Zool. Vol.11. No.2. P.315-324.

KEY WORDS: Stichodactyla haddoni, anemonefish, growth, survival, captivity.

\section{Захватническое поведение, рост и выживание морских анемонов Stichodactyla haddoni Saville-Kent, 1893, ассоциированных с рыбами-клоунами}

\author{
Дж. Баламуруган, Т.А. Кумар, С. Гош
}

РЕЗЮМЕ: В течение 168 дней были исследованы поведение, рост и выживание морских анемонов Stichodactyla haddoni в неволе при воздействии различных условий. Каждый эксперимент был продолжен через 8 недель. Эксперименты проводились при стандартных показателях водной среды и фотопериодичности. Морские анемоны были подразделены на две группы: первая содержалась вместе с рыбамиклоунами, вторая - без рыб. Распространение и рост анемонов замеряли каждую 
неделю. Было обнаружено, что анемоны, содержащиеся в присутствии рыб-клоунов, обнаруживают существенно большие темпы роста орального диска $(\mathrm{p}<0,01)$ и их значительную вариацию $(\mathrm{p}<0,05)$ в зависимости от вида рыб по сравнению с теми анемонами, которые содержались без рыб. Экспоненциальный рост показали те анемоны, которые содержались в присутствии естественных для анемонов видов рыб-клоунов. Темпы роста у анемонов, содержащихся с рыбами были на 10-15\% выше, чем темпы роста анемонов, содержащихся без рыб. В период вынужденного голодания выживаемость анемонов, содержащихся с рыбами, составила 80\%, а у анемонов, содержащихся без рыб - $60 \%$. Критерий хи-квадрат выявил существование существенной корреляции между поведением анемонов и присутствием рыб $\left(\chi^{2}=\right.$ $25,019, \operatorname{df}(7), \mathrm{p}<0,01)$. Результаты этого эксперимента показали усиление экспансии, роста и выживаемости у анемонов в присутствии рыб.

Как цитировать эту статью: Balamurugan J., Ajith Kumar T.T., Ghosh S., 2014. Expansion behavior, growth, and survival of the sea anemone Stichodactyla haddoni (SavilleKent, 1893) with anemonefishes captivity // Invert. Zool. Vol.11. No.2. P.315-324.

КЛЮЧЕВЫЕ СЛОВА: Stichodactyla haddoni, рыбы-клоуны, рост, выживаемость, содержание в неволе.

\section{Introduction}

The sea anemone Stichodachtyla haddoni (Saville-Kent, 1893) inhabits mid tide levels up to depths with sufficient light penetration and prefers to burrow its column into soft sediments (Dunn, 1981; Fautin et al., 2009). Individuals of this species occur in shallow tropical and sub tropical seas ranging from the Red Sea through the Indian Ocean up to New Calidonia and from Japan through Singapore to Australia (Dunn, 1981; Fautin, Allen, 1997; Fautin et al., 2009). The Haddon's anemone has an undulating oral disc, which is broad flat to shallow in shape and it is densely covered with hundreds of slightly tapering tentacles. The yellow-orange coloured area around the mouth is bare. Pedal disc is narrower than the oral disc. The column is white in colour. Pink or purple coloured verrucae can be seen on the column tapering towards the pedal disc (Dunn, 1981; Fautin, Allen, 1997).

Many sea anemones can be kept under various conditions including non-circulating water and also without hosting a fish (Stephenson, 1928; Fautin, Allen, 1997). The growth rate of sea anemones varies between juvenile and adolescents, due to increased feeding behavior (Ashworth, Annandale 1904). Sea anemones may shrink during starvation or stress (Sebens, 1979; Roopin, Chadwick, 2009). The non-reproducing anemones respiration is rated as the main energy sink (Shick, 1991) and the respiration rate depends on temperature and many other factors (Szczebak et al., 2013). For their growth and reproduction, anemones can use the photosynthetic products from zooxanthellae (Achituv, Dubinsky, 1990). Measuring the body size of a sea anemone accurately is difficult as it may hold varying amounts of water in the coelenteron at different times producing errors in wet mass measurements (Stephenson, 1928; Chomsky et al., 2004). The anemone selected for this experiment, $S$. haddoni is one of the ten species of anemones that host anemonefishes (Fautin, Allen, 1997).

Reef Cnidarians enjoy multiple benefits through endosymbiotic micro algal dinoflagellates and macrosymbionts as fish, mollusks and crustaceans (Venn et al., 2008; Randall, Fautin, 2002; Patzner, 2004; Chadwick et al., 2008; Roopin et al., 2011). Sea anemones that host the anemonefishes is also harbor zooxanthellae as a rule (Dunn, 1981) that supply the host with energy rich photosynthetic compounds for respiration, growth and reproduction (Steen, 1988; Achituv, Dubinsk 1990; Whitehead, Douglas, 
2003). It has been reported that anemones survive and grow better in the wild, when they harbor anemone fishes as symbionts (Porat, Chadwick-Furman, 2004; Holbrook, Schmit, 2005; Huebner et al., 2012). Although anemone biology is not understood completely, it is seen that metabolic energy deficiencies can cause a decrease in poly biomass. Thus, the body size of an anemone may not be directly related to poly age, but be related closely to its nutritional history (Stephenson, 1928; Roopin, Chadwick, 2009). Current study reports reveal that an increase in the expansion behavior, growth and rate of survival of the host anemone in captivity in the presence and absence of anemone fishes.

\section{Materials and Methods}

\section{Experiment design}

Totally, 45 nos. of sea anemone, S. haddoni and 60 nos. of anemone fishes (Amphiprion polymnus, A. nigripes, A. perideraion, A. ocellaris, A. frenatus, A. sebae, A. clarkii, A. sandaracinos, A. melanopus and Premnas biaculeatus) were procured from the traders at Chennai, India. The information obtained from the supplier reveal that the fishes and anemones had been collected from the coral archipelago of Indian waters. The animals were transported to a closed system hatchery at the Centre of Advanced Study in Marine Biology, Annamalai University. They were packed in polythene bags with water and oxygen and carefully acclimatized to the rearing system, before releasing to the experimental set-up.

Every two days, food remnants and other accumulated wastes were siphoned and $10 \%$ of water change was carried out. A canister filter (Eheim, Germany) was placed on inside the tank to maintain the water quality. Temperature $27 \pm$ $1^{\circ} \mathrm{C}$, salinity $26 \pm 0.5 \mathrm{psu}$, dissolved oxygen $5.5 \pm$ $0.5 \mathrm{ml}^{-1}$ and $\mathrm{pH} 7.5 \pm 0.2$ were maintained in all tanks uniformly during the whole period of the study. The photoperiod was maintained at $13 \mathrm{~L}$ \& 11D with $18-20 \mathrm{~m} \mathrm{~mol}^{-1} \mathrm{sec}^{-1}$ (CW Fluorescent bulb $(200 \mathrm{~W})$. The animals were fed daily with prawn and muscle meat along with frozen fish. The anemones and fishes selected for the study were of similar size to ensure the accuracy of the observations.

A Vernier caliper calibrated with an error of $0.1 \mathrm{~mm}$ was used to measure the diameter of the oral and pedal discs. The diameter of the oral disc was taken as measure of expansion and the pedal disc was calculated as measure of growth rate (Porat, Chadwick Furman, 2004; Brace, Quicke, 1986).

\section{Growth measurements of solitary} anemones

Healthy anemones $(\mathrm{N}=15$, Size $=15.4 \mathrm{~cm}$ $(\mathrm{SE} \pm 1.3)$ were transferred to the separate experimental tanks holding 500 liters $(150 \times 60$ x $60 \mathrm{~cm})$ of conditioned sea water. Tanks were marked S1 to S15. The diameters of the oral and pedal discs were taken at weekly intervals, throughout the 8-week of study period.

\section{Growth measurements of anemones} hosting fish

Ten species of paired anemonefishes were introduced to the tanks with individual anemones separately. The introduced pairs took few minutes to hours to be acquainted with the new host. The average body length of the introduced anemone was $15.4 \mathrm{~cm}(\mathrm{SE} \pm 1.34 \mathrm{~cm})$. The diameter of the oral disc was measured in these anemones at weekly intervals throughout the study period. Based on the association of a fish with the anemone in wild, the fishes were categorized as native and nonnative species in association with the anemone (Allen, Fautin, 1997; Rema, Madhu, 2007).

\section{Survival of anemones in both groups}

Once the growth experiment was concluded, the set up was continued in order to study the effect of anemonefishes on their survival with the anemone. Anemones in both the groups were allowed to starve and fed them, once in a week. The solitary group had 15 anemones in individual tanks. The hosting group had 30 anemones in the group with pairs of different species of anemonefishes in their individual tanks. Release of excess mucus, shrinking, wide- 


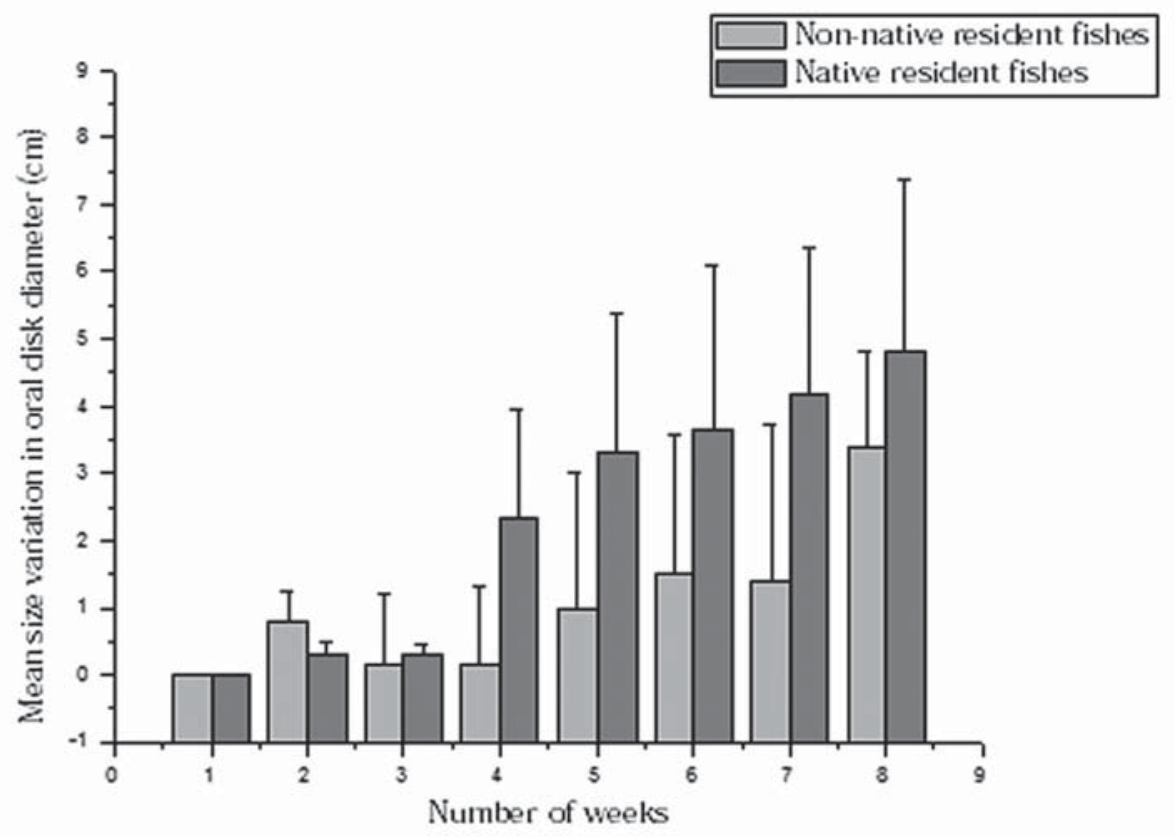

Fig. 1. Expansion rate of oral disc diameter $(\mathrm{cm})$ in Stichodactyla haddoni in the presence native inhabited and non-inhabited anemonefish.

Рис. 1. Увеличение диаметра орального диска у Stichodactyla haddoni в условиях присутствия и отсутствия рыб-клоунов.

open mouth and strong decaying smell were taken as signs of death in the anemones. The relative number of anemones that did not die and decayed was taken as surviving number of anemones to calculate the percentages of survival.

\section{Analysis of data}

The standard statistical tool SPSS version number 16.0 (Norusis, 2009) was used for carrying out the statistical analysis. ANOVA, ChiSquare and Multiple Regression tests were carried out to determine the significance of the correlation between different species of anemone fishes and the wellbeing of the anemones, namely their expansion, growth and survival.

\section{Results}

Under the experimental conditions, the expansion rate of the solitary anemones showed variance between individuals. In comparison, a significant increase (ANOVA F ${ }_{29,210}=11.27$, $\mathrm{p}<0.01$ ) of the oral disc was observed in anemones hosting fishes. The expansion showed a steady increase, once the acclimation of the resident fish with the host was completed (Fig. 1). The maximum increase of $12.83 \pm 2.5 \mathrm{~cm}$ was seen, when the anemone was hosting $A$. polymnus. Anemones cohabitating with $A$. sandaracinos and P. biaculaetus showed an oral disc increase next to those with A. polymnus, which was up to $8.83 \pm 0.28 \mathrm{~cm}$ and $4.83 \pm 1.25$ $\mathrm{cm}$ respectively. The effect of cohabitating fish such as $A$. melanopus, A. frenatus, A. perideraion and $A$. nigripes has influenced to increase the size of the anemone's oral disk up to $1.56 \pm 0.02 \mathrm{~cm}, 1.02 \pm 0.02 \mathrm{~cm},-7.5 \pm 3.04 \mathrm{~cm}$ and $-12 \pm 5.29 \mathrm{~cm}$ respectively. The influence of A. sebae, A. clarkii, A. sandaracinos and A. ocellaris showed no variations among themselves in increasing the diameter of the oral disc of the anemones. However, considerable variation was seen (Table 1) among other species as 
Table 1. Analysis of variance (ONEWAY ANOVA) to determine variation between anemonefish and on its host anemone expansion rate.

Таблица 1. Анализ отклонения (дисперсионный анализ), определяющего зависимость между видом рыбы-клоуна и ростом морских анемонов.

\begin{tabular}{|c|c|c|c|c|c|}
\hline $\begin{array}{l}\text { S. } \\
\text { No. }\end{array}$ & $\begin{array}{c}\text { Fish species } \\
\text { Вид рыбы }\end{array}$ & $\begin{array}{c}\text { Mean } \\
\text { Среднее }\end{array}$ & $\begin{array}{c}\text { Standard deviation } \\
\text { (SD } \pm \text { ) } \\
\text { Стандартное } \\
\text { отклонение }\end{array}$ & F-Value & P-Value \\
\hline 1 & Amphiprion polymnus & $28.85^{\mathrm{h}}$ & 3.24 & \multirow{10}{*}{2071.18} & \multirow{10}{*}{$<0.001^{*}$} \\
\hline 2 & Amphiprion sebae & $15.87^{\mathrm{d}}$ & 0.78 & & \\
\hline 3 & Amphiprion clarkii & $15.62^{\mathrm{d}}$ & 1.15 & & \\
\hline 4 & Amphiprion sandaracind & $18.68^{\mathrm{f}}$ & 1.42 & & \\
\hline 5 & Amphiprion frenatus & $10.87^{\mathrm{b}}$ & 0.80 & & \\
\hline 6 & Amphiprion ocellaris & $18.66^{\mathrm{f}}$ & 0.82 & & \\
\hline 7 & Amphiprion nigripes & $13.69^{c}$ & 3.32 & & \\
\hline 8 & Amphiprion percula & $7.90^{\mathrm{a}}$ & 1.35 & & \\
\hline 9 & Amphiprion melanopus & $21.69^{\mathrm{g}}$ & 4.84 & & \\
\hline 10 & Premnas biaculeatus & $17.90^{\mathrm{e}}$ & 2.11 & & \\
\hline
\end{tabular}

* significant at the level of $1 \%$

* значимость $1 \%$

$\mathrm{a}, \mathrm{b}, \mathrm{c}, \mathrm{d}, \mathrm{e}, \mathrm{f}, \mathrm{g}, \mathrm{and} \mathrm{h}$ superscripts determines significance at 5\% level based on DMR test.

$\mathrm{a}, \mathrm{b}, \mathrm{c}, \mathrm{d}, \mathrm{e}, \mathrm{f}, \mathrm{g}$, and h

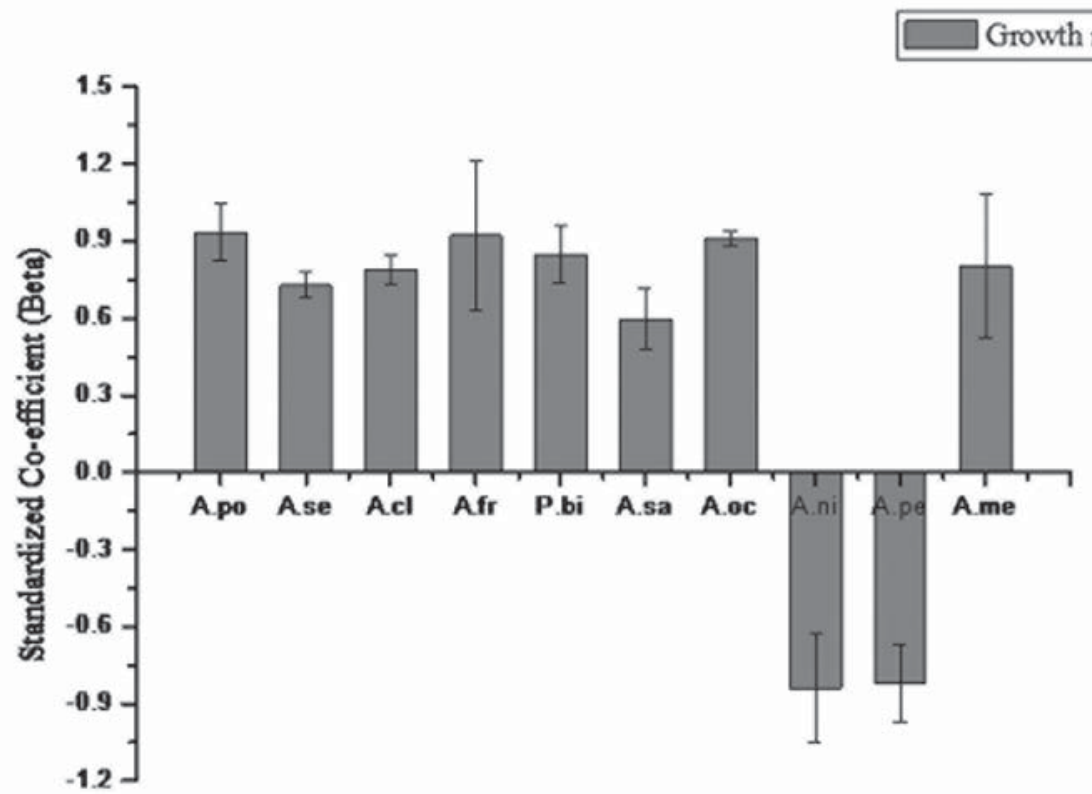

Fig. 2. Multiple regression analysis of sea anemone growth rate.

A.po - A. polymnus, A.se - A. sebae, A.cl - A. clarkii, A.fr - A.frenatus, P.bi - P. biaculeatus, A.sa - A. sandaracinos, A.oc - A.ocellaris, A.ni - A. nigripes, A.pe - A. perideraion, and A.me - A. melanopus (standardized coefficient (b) values $(\mathrm{S} . \mathrm{E} \pm)$ ). Enter mode analysis showed both exponential increase and decrease in growth based on their native inhabited and non-inhabited fish species.

Рис. 2. Множественный регрессионный анализ роста морских анемонов.

A.po - A. polymnus, A.se - A. sebae, A.cl - A. clarkii, A.fr - A.frenatus, P.bi - P. biaculeatus, A.sa - A. sandaracinos, A.oc - A.ocellaris, A.ni - A. nigripes, A.pe $-A$. perideraion, and A.me $-A$. melanopus (стандартный коэффициент (b) оценка (S.E \pm )). Анализ показывает экспоненциальное увеличение и уменьшение роста анемонов в зависимости от присутствия или отсутствия рыб-клоунов. 


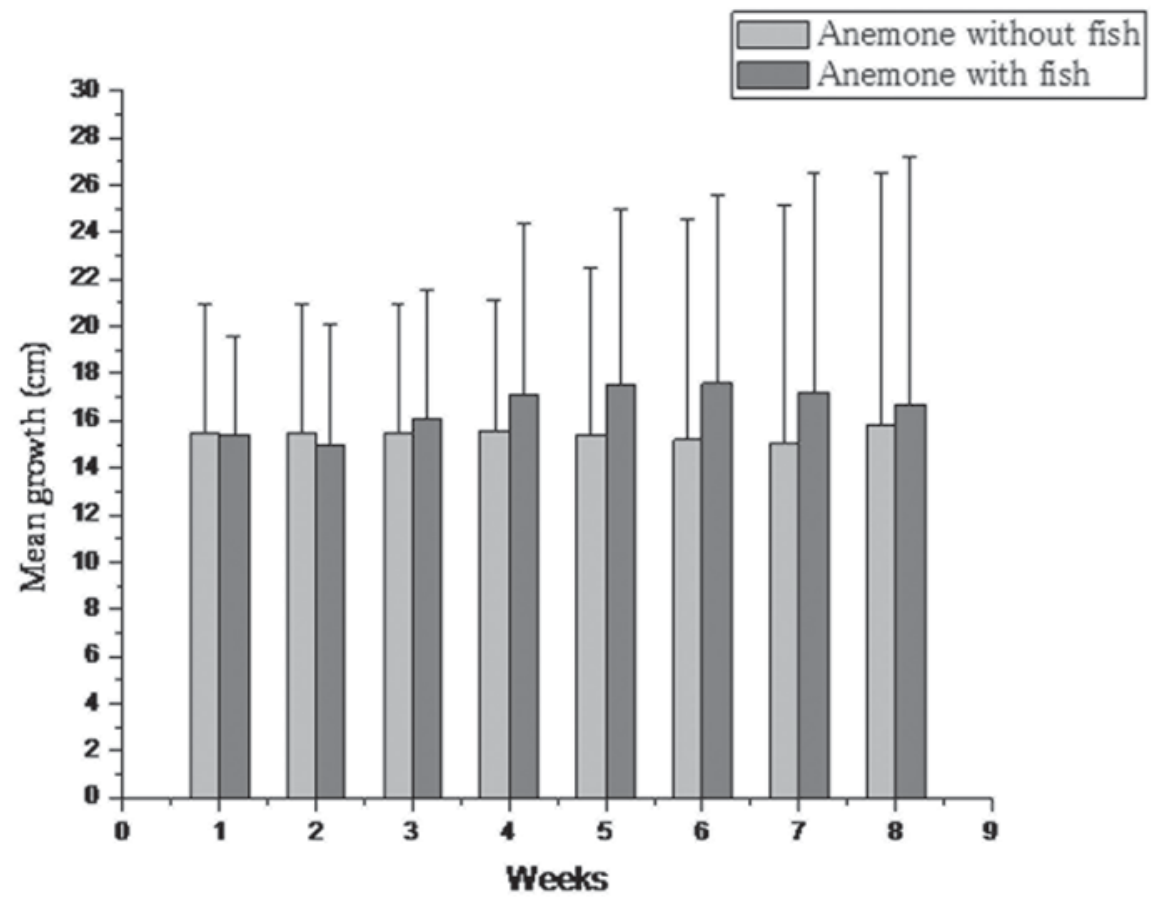

Fig. 3. Mean growth rate of Stichodactyla haddoni in the presence and absence of fish throughout the experimental period (8 weeks).

Рис. 3. Средняя величина роста Stichodactyla haddoni в условиях присутствия и отсутствия рыбклоунов за весь период эксперимента (8 недель).

confirmed by the Duncan Multiple Range Test (DMRT).

Mean growth rate of the anemones hosting with fish varied significantly between individuals depending on the species of fish hosted by them (ANOVA, $\mathrm{F}_{9,210}=2071.18, \mathrm{p}<0.001$ ) the growth rate was observed as $35-40 \%$ increase from the initial size. The rate of growth was significantly associated with the fact whether the anemones were hosting the fish or not (Table 2). Multiple regression analysis of the growth rate of the anemones showed an exponential character for the combinations of anemone fish and anemones for the particular species (Fig. 2). It should also be noted that an exponential decrease of growth was seen in $A$. nigripes and A. perideraion associated anemones. The anemones, which were not hosting any fish showed a growth rate around $20-25 \%$ against $35-40 \%$ showed by the anemones hosting with fishes. Furthermore, multiple regression analysis on growth rate of host anemone with residents like A. polymnus $\left(R^{2}=0.87, \mathrm{t}=-9.19, \mathrm{p}<0.001\right), A$. sebae $\left(R^{2}=0.51, \mathrm{t}=-4.33, \mathrm{p}<0.05\right)$, A. clarkii $\left(R^{2}=0.67, \mathrm{t}=-5.95, \mathrm{p}<0.001\right)$, A. sandaracinos $\left(R^{2}=0.31, \mathrm{t}=-2.44, \mathrm{p}<0.05\right)$, A. frenatus $\left(R^{2}=0.84, \mathrm{t}=-9.31, \mathrm{p}<0.001\right)$, A. ocellaris $\left(R^{2}=0.81, \mathrm{t}=-9.28, \mathrm{p}<0.001\right)$, A. melanopus $\left(R^{2}=0.62, \mathrm{t}=-2.48, \mathrm{p}<0.05\right)$ and $P$. biaculeatus $\left(R^{2}=0.71, \mathrm{t}=-5.36, \mathrm{p}<0.001\right)$ showed an exponential increase. An exponential growth decrease was recorded in $A$. nigripes $\left(R^{2}=0.69, \mathrm{t}=\right.$ 12.3, $\mathrm{p}<0.001)$ and $A$. perideraion $\left(R^{2}=0.65, \mathrm{t}=\right.$ 12.5, $\mathrm{p}<0.001$ ) (Fig. 2).

In the survival of anemones, it was seen that those who didn't increased in size or shrank, they were ultimately died. During a period of 8 weeks starvation, $80 \%$ of the anemones hosting fish survived as against $60 \%$ of the survival in non-hosting group (Fig. 4). In Chi Square analysis, the survival rate of the hosting group of anemones was seen to be $54.1 \%$ and the non- 
Table 2. Chi-square analysis to find out the significant relationship between growth rate of anemone with native and non-native resident fishes.

Таблица 2. Анализ критерия хи-квадрат для оценки влияния на рост анемонов пребывания с естественными и неестественными видами рыб-клоунов.

\begin{tabular}{|c|c|c|c|c|c|}
\hline $\begin{array}{l}\text { S. } \\
\text { No. }\end{array}$ & $\begin{array}{l}\text { Fish species } \\
\text { Вид рыбы }\end{array}$ & $\begin{array}{c}\text { Native } \\
\text { степень сродства } \\
\text { к анемнонам }\end{array}$ & $\begin{array}{c}\text { Non-Native } \\
\text { степень сродства } \\
\text { к анемнонам }\end{array}$ & $\begin{array}{l}\text { Chi- } \\
\text { square } \\
\text { value }\end{array}$ & P-value \\
\hline 1 & $\begin{array}{l}\text { Amphiprion } \\
\text { polymnus }\end{array}$ & $\begin{array}{c}683 \\
(32.2 \%)\end{array}$ & - & \multirow{10}{*}{3960.0} & \multirow{10}{*}{$<.001^{*}$} \\
\hline 2 & $\begin{array}{l}\text { Amphiprion } \\
\text { sebae }\end{array}$ & $\begin{array}{c}380 \\
(17.9 \%)\end{array}$ & - & & \\
\hline 3 & $\begin{array}{c}\text { Amphiprion } \\
\text { clarkii }\end{array}$ & $\begin{array}{c}373 \\
(17.6 \%)\end{array}$ & - & & \\
\hline 4 & $\begin{array}{c}\text { Amphiprion } \\
\text { sandaracinos }\end{array}$ & - & $\begin{array}{c}445 \\
(24.2 \%)\end{array}$ & & \\
\hline 5 & $\begin{array}{l}\text { Amphiprion } \\
\text { frenatus }\end{array}$ & $\begin{array}{c}260 \\
(12.3 \%)\end{array}$ & - & & \\
\hline 6 & $\begin{array}{l}\text { Amphiprion } \\
\text { ocellaris }\end{array}$ & - & $\begin{array}{c}447 \\
(24.3 \%)\end{array}$ & & \\
\hline 7 & $\begin{array}{c}\text { Amphiprion } \\
\text { nigripes }\end{array}$ & - & $\begin{array}{c}295 \\
(16.0 \%)\end{array}$ & & \\
\hline 8 & $\begin{array}{c}\text { Amphiprion } \\
\text { percula }\end{array}$ & - & $\begin{array}{c}161 \\
(8.8 \%)\end{array}$ & & \\
\hline 9 & $\begin{array}{l}\text { Amphiprion } \\
\text { melanopus }\end{array}$ & - & $\begin{array}{c}492 \\
(26.7 \%)\end{array}$ & & \\
\hline 10 & $\begin{array}{c}\text { Premnas } \\
\text { biaculeatus }\end{array}$ & $\begin{array}{c}424 \\
(20.0 \%)\end{array}$ & - & & \\
\hline
\end{tabular}

* Significant at $1 \%$ level

* значимость $1 \%$

Values within () bracket shows the column value

Значение в скобках () показывает долю в процентах

hosting group, it was $45.1 \%$. The presence or absence of a hosted fish and the ability of the anemone to survive in the starving period showed a strong association $\left(\mathrm{c}^{2}=25.019, \mathrm{df}(7), \mathrm{p}<0.01\right)$. It was seen that the survivability of the sea anemone, $S$. haddoni during starvation was enhanced by the presence of hosted anemone fish. Further, the rate of growth of the sea anemone $S$. haddoni was seen to be higher, when hosting the species of natural choice (that it prefers to host in nature). However, the survival depended on the availability of hosted fish with no particular preference to the fish species.

\section{Discussion}

The mutual relationship between anemone fish and their host anemones in coral reefs has been known for a limited species (Fautin, Allen, 1997). It is seen that the relationships between 30 species of anemone fishes of the genera Amphiprion and Premnas and 10 anemones belonging to the order Actiniaria (Fautin, Allen, 1997; Allen et al., 2010). The fish cannot survive in nature without safety of the tentacles of the hosting anemones (Mariscal, 1970; Allen, 1972; Fautin, Allen, 1997). However, both co- 


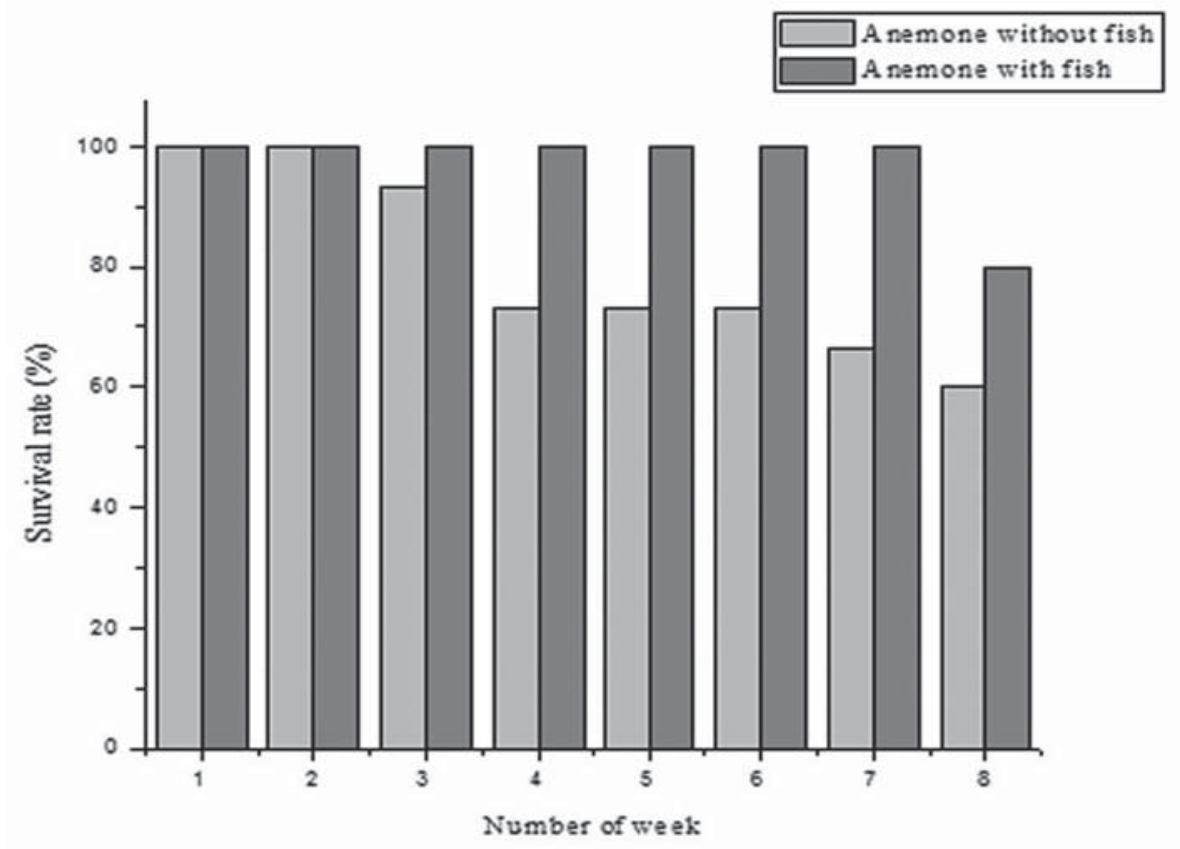

Fig. 4. Percentage survival of Stichodactyla haddoni during starvation with and without anemonefish (8 weeks).

Рис. 4. Выживаемость (в процентах) Stichodactyla haddoni в период голодания и существования без рыб-клоунов за весь период эксперимента (8 недель).

habitants can survive in aquaria (Fautin, Allen, 1997).

Fish utilize these habitats for a variety of activities such as feeding, resting and as sites for reproduction (Fautin, Allen, 1997; Arvedlund et al., 2000). Despite their ubiquity, the exact nature of these associations is often not understood well (Holbrook, Schmitt, 2005; Huebner et al., 2012). In addition to their host of preference, fish have also been forced to associate with anemones other than their natural preference in the wild. It is seen that the anemones and fish grow faster in the wild as well as in captive conditions when cultured together (Porat, Chadwick-Furman, 2005). Furthermore, the spawning efficiency of a resident fish was higher, when they were held with sessile host anemones in aquaria (Balamurugan et al., 2013).

The expansion response of the host anemones to their fish symbionts appears to be adaptive, in that it allows them to expose their endo- symbiotic zooxanthellae to light in the presence of anemone fish (Porat, Chadwick-Furman, 2004). Anemones could potentially derive direct and indirect nutritive benefits from the fish occupying them. Anemones may directly ingest particles dropped by the fish hosted by the fish or absorb their waste, which could provide sources of regenerated nitrogen (Roopin et al., 2007), sulfur and phosphorus (Godinot, Chadwick, 2009).

It was seen in this study that the expansion of the oral disc was greater when the anemone hosted the fish by its natural choice, rather than when hosting other species. It could be that the innate immunity of the fish to its natural host helps the fish to acclimatize quicker and settle down with them quickly. Roopin and Chadwick (2009) suggested that the typical behavior of the fish in swimming and fanning on the tentacles of the anemone during feeding would expand the oral disc (tentacle crown) more than in the 
solitary anemones. Dependence of long-term growth, expansion and survival of E. quadricolor depends on both numbers and size of its resident anemone fish depicts the strong benefits of this association (Porat, Chadwick-Furman, 2004). Therefore, the negative expansion of the oral disc would indicate the shrinkage of anemone tentacles from their initial size due to the absence of fanning and dissociation behavior of anemone fish from the host.

Based on the current study, the growth rate of the sea anemones associated with hosted fish (35-40\%) showed an increase of $10-15 \%$ in comparison with anemones not associated with fish (20-25\%). Thus, the anemone fish appear to provide physiological benefits to their host anemones in large part through their contribution of excreted ammonia and act as a primary factor of controlling the zooxanthellae in the host anemones (Roopin, Chadwick, 2009). In times of scarcity of food, host feeding and the anemone's catabolism are often insufficient to supply the complete nitrogen requirement of the zooxanthellae (Rahav et al., 1989).

During the period of starvation, the solitary anemones $S$. haddoni had a low survival rate of $60 \%$ in comparison to the higher survival rate of $80 \%$ in the anemones hosting fishes. This suggests that the presence of the fish hosted by the anemone has an influence on the growth and survival of host anemones in captivity. Spotte (1996) and Roberts et al. (1999) suggested that the source of nitrogen could be extremely beneficial as it can be limiting in these systems and anemones may take up even small amounts of nitrogen. The presence of even one adult fish with the anemone may supply sufficient quantities of ammonia and other nutrients (Cleveland et al., 2008; Godinot, Chadwick, 2009; Roopin et al., 2011). Porat and Chadwick-Furman (2004) and Roopin et al (2008) reported that sea anemones that had been maintained without anemone fish for four weeks took up ammonia from enriched water at a faster rate than those that had been kept with anemone fish, which absorbed very little ammonia. Based on this, they concluded that anemone fish provides ammonia to their host anemones and the zooxanthellae they harbor, which enhances the rates of tissue growth and regeneration.

During the period of starvation, the anemones hosting fish had a better chance of obtaining nitrogen than those without any hosted fish. This provided them with a better chance of survival in comparison with the solitary anemones during the starvation period. In this study, we have reached the conclusion as reported in the earlier studies, that the expansion, growth and survival of anemones in captivity is associated with the size, numbers and the species of anemone fish associating with it.

\section{Acknowledgements}

Authors are grateful to the authorities of Annamalai University for providing facilities and the National Fisheries Development Board for financial support to carry out the study.

\section{References}

Achituv Y., Dubinsky Z. 1990. Carbon budgets in marine, Mutualistic association between microalgae and cnidarians // Karger, Basel Mellinger J. (eds.). Nutrition in wild and domestic animals. P.36-48.

Allen G.R., Drew J., Fenner D. 2010. Amphiprion pacificus, a new species of anemonefish (Pomacentridae) from Fiji, Tonga, Samoa, and Wallis Island // Aqua Int. J. Ichthyol. Vol.16 P.129-138.

Allen G.R. 1972. The Anemonefishes: Their classification and Biology. Neptune city, New Jersey: T.F.H. Publication Inc. 288 pp.

Arvedlund M., Bundgaard I., Nielsen L.E. 2000. Host imprinting in anemonefishes (Pisces: Pomacentridae): Does it dictate spawning site preferences? // Env. Biol. Fishes Vol.58. P.203-213.

Ashworth J.H., Annandale N. 1904. Observations on some aged specimens of Sagartia troglodytes, and on the duration of life in coelenterates // Proc. R .Soc. Edinb. Vol.25. P.295-308.

Balamurgan R.J., Ajith Kumar T.T., Balasubramanian T. 2013. Influence of host anemone (Stchodactyla haddoni, Saville-Kent, 1983) locomotion on its resident anemonefish reproduction // Ani. Rep. Sci. Vol.140. P.103-107.

Brace R.C., Quicke D.L.J. 1986. Seasonal changes in dispersion within an aggregation of the anemone, Actinia equina, with a reappraisal of the role of intraspecific aggression // J. Mar. Biol. Assoc. U.K. Vol.66. P.49-70.

Chadwick N.E., Duris W., Horka I. 2008. Biodiversity and behavior of shrimps and fishes symbiotic with sea anemones in the Gulf of Aqaba, northern Red Sea // Por F.D. (ed.). Aqaba-Eliat, The improbable gulf: 
environment, biodiversity and preservation. Hebrew University, Jerusalem: Magnes Press. P.209-223.

Chomsky O., Kamenir Y., Hyams M., Dubinsky Z., Chadwick-Furman N.E. 2004. Effects of feeding regime on growth rate in the Mediterranean sea anemone Actinia equina // J. Exp. Mar. Biol. Ecol. Vol.299. No.2. P.217-229.

Cleveland A., Verde E.A., Lee R. 2008. Nutritional exchange in the anemonefish/anemone symbiosis: Photosynthetical-fixed carbon is translocated to host fish. Abstract, $11^{\text {th }}$ Int. Coral Reef Symposium. Fort Lauderdale, Florida, US (http://www.nova.edu/ncri/11icrs/ index.html).

Dunn D.F. 1981. The anemonefish sea anemones: Stichodactylidae (Coelenterata: Actiniaria) and other sea anemones symbiotic with pomacentrid fishes // Transactions of the American Philosophical Society. Vol.71. P.1-115.

Fautin D.G. 1991. The anemonefishes symbiosis: What is known and what is not// Symbiosis. Vol.10. P.23-46.

Fautin D.G., Allen G.R. 1997. Anemonefishes and their host sea anemones: a guide for aquarists and divers, Revised edition. Perth: Western Australia Museum. 160 p.

Fautin D.G., Tan S.H., Ria Tan 2009. Sea anemones (Cindaria: Actiniaria) of Singapore: abundant and well-known shallow-water species // Raff. Bull. Zool. Vol.22. P.121-143.

Godinot C., Chadwick N.E. 2009. Phosphate excretion by anemonefish and uptake by giant sea anemones: demand outstrips supply // Bull. Mar. Sci. Vol.85. P.1-9.

Godwin J., Fautin D.G. 1992. Defense of host actinians by anemonefishes // Copeia. Vol.3. P.902-908.

Holbrook S.J., Schmitt R.J. 2005. Growth, reproduction and survival of a tropical sea anemone (Actinaria): benefits of hosting anemonefish // Coral Reefs. Vol.24. P.67-73.

Huebner L.K., Dailey B., Titus B.M., Khalaf M., Chadwick N.E. 2012. Host preference and habitat segregation among Red sea anemonefish: effect of sea anemone traits and fish life stages // Mar. Eco. Prog. Ser. Vol.464. P.1-15.

Hughes T.P. 1984. Population dynamics based on individual size rather than age: a general model with coral reef example // Am. Nat. Vol.123. P.778-779.

Jackson J.B.C., Hughes T.P. 1985. Adaptive strategies of coral reef invertebrate // Am. Sci. Vol.73. P.265-274.

Mariscal R.N. 1970. The nature of the symbiosis between Indo-Pacific anemone fishes and sea anemones // Mar. Biol. Vol.6. P.58-65.

Norusis M.J. 2009. SPSS 16.0 Guide to Data Analysis. Prentice-Hall, Upper Saddle River, NJ. 672 p.

Patzner R.A. 2004. Association with sea anemones in the Mediterranean Sea: a review // Ophelia. Vol.58. P.1-11.

Porat D., Chadwick-Furman N.E. 2004. Effect of anemonefish on giant sea anemones: expansion behavior, growth, and survival // Hydrobiologia. Vol.530/531. P.513-520.

Porat D., Chadwick-Furman N.E. 2005. Effect of anemonefish on giant sea anemone: ammonium uptake, zoox- anthella content and tissue regeneration// Mar. Freshw. Behav. Phys. Vol.38. P.43-51.

Rahav O., Dubinsky Z., Achituv Y., Falkowski P.G. 1989. Ammonium metabolism in the zooxanthellate coral, Stylophora pistillata // Proc. R. Soc. Lond. Ser.B. Vol.236. P.325-337.

Randall J.E., Fautin D.G. 2002. Fishes other than anemonefishes that associate with sea anemones // Coral Reefs. Vol.21. P.188-190.

Rema M., Madhu, K. 2007. Occurrence of anemonefish and host sea anemones in Andaman and Nicobar Islands // J. Mar. Biol. Ass. India. Vol.49. No.2. P.118-126.

Roberts J.M., Davies P.S., Fixter L.M. 1999. Symbiotic anemones can grow when starved: nitrogen budget for Anemonia viridis in ammonium-supplemented seawater // Mar. Biol. Vol.133. P.29-35.

Roopin M., Henry R.P., Chadwick N.E. 2008. Nutrient transfer in a marine mutualism: Patterns of ammonia excretion by anemonefish and uptake by giant sea anemones // Mar. Biol. Vol.154. P.547-556.

Roopin M., Chadwick N.E. 2009. Benefits to host sea anemones from ammonia contributions of resident anemonefish // J. Exp. Mar. Biol. Ecol. Vol.370. P.27-34.

Roopin M., Thornhill D.J., Santos S.R., Chadwick N.E. 2011. Ammonia flux, physiological parameters, and Symbiodinium diversity in the anemonefish symbiosis on Red Sea coral reefs // Symbiosis. Vol.53. P.63-74.

Sebens K.P. 1979. The regulation of a sexual reproduction and indeterminate size in the sea anemone $\mathrm{An}$ thopleura elegantissima (Brandt) // Biol. Bull. Vol.158. P.370-382.

Saville-Kent W. 1893. The Great Barrier Reef of Australia; Its products and potentialities. London: W.H. Allen \& Co. 387 p.

Shick J.M. 1991. A Functional Biology of Sea Anemones. Chapman \& Hall. 395 p.

Spotte S. 1996. Supply of regenerated nitrogen to sea anemones by their symbiotic shrimp // J. Exp. Mar. Bio. Ecol. Vol.198. P.27-36.

Steen R.G. 1988. The bioenergetics of symbiotic sea anemones (Anthozoa: Actiniaria) // Symbiosis. Vol.5. P.103-142.

Stephenson T.A. 1928. The British Sea Anemones. London: Ray Society. Vol.1. 148 p.

Szczebak J.T., Henry R.P., Al-Horani F.A., Chadwick N.E. 2013. Anemonefish oxygenate their anemone hosts at night // J. Exp. Biol. Vol.216. P.970-976.

Venn A.A., Loram J.E., Douglas A.E. 2008. Photosynthetic symbioses in animals // J. Exp. Bot. Vol.59. P.10691080.

Whitehead L.F., Dogulas A.E. 2003. Metabolite comparisons and the identity of nutrients translocated from symbiotic algae to an animal host // J. Exp. Biol. Vol.206. P.3149-3157.

Responsible editor E.N. Temereva 